\title{
Mixtures of Coal Ash and Compost as Substrates for Highbush Blueberry
}

\author{
Brent L. Black ${ }^{1}$ and Richard H. Zimmerman ${ }^{2}$ \\ United States Department of Agriculture, Agricultural Research Service, Henry A. Wallace Beltsville Agricultural \\ Research Center, Fruit Laboratory, Building 010A, 10300 Baltimore Avenue, Beltsville, MD 20705-2350
}

\begin{abstract}
AdDITIONAL INDEX WORDs. Vaccinium, sewage sludge
AвsTRACT. Bottom ash from a coal-fired power plant and two composts were tested as components of soil-free media and as soil amendments for growing highbush blueberry (Vaccinium corymbosum $\mathbf{L}$.). Combinations of ash and compost were compared to Berryland sand, and Manor clay loam, and compost amended Manor clay loam. The pH of all treatment media was adjusted to 4.5 with sulfur at the beginning of the experiment. In 1997, plants of 'Bluecrop' and 'Sierra' were planted in $15-\mathrm{dm}^{3}$ pots containing the $\mathrm{pH}$-adjusted treatment media. The first substantial crop was harvested in 1999. At the end of the 1999 season, one half of the plants were destructively harvested for growth analysis. The remaining plants were cropped again in 2000. Yield and fruit size data were collected in both seasons, and leaf and fruit samples were collected in 1999 for elemental analysis. The presence of coal ash or composted biosolids in the media had no detrimental effect on leaf or fruit elemental content. Total growth and yield of both cultivars was reduced in clay loam soil compared to Berryland sand, whereas growth and yield of plants in coal ash-compost was similar to or exceeded that of plants in Berryland sand.
\end{abstract}

The cultivars of highbush blueberry have been derived primarily from selections of Vaccinium corymbosum L., which are naturally adapted to acidic, swampy conditions (Eck et al., 1990). Under cultivation, these plants prefer low-pH, moist, well-drained, sandy soils containing high levels of organic matter. These soil requirements effectively limit the number of suitable sites for commercial production to a few specific geographic regions (Eck and Childers, 1966; Pritts, 1992).

In the more populated regions of the United States, direct marketing of fruit, either on farm or at local farm markets, is becoming more prevalent, as indexed by the growth in farm markets between 1994 and 2000 (Holley, 2000). In many regions however, the relatively specific site and soil requirements of highbush blueberry has limited their ability to be produced on diversified, directmarket oriented fruit farms. These farms, by nature, are located near population centers, and may or may not have sites suitable for highbush blueberry production.

A number of research efforts have focused on these limitations. Extensive effort has been expended in breeding for upland soil adaptability (Finn et al., 1993a, 1993b; Korcak, 1988a, 1989; Korcak et al., 1982; Scheerens et al., 1999), which has yet to produce upland soil-adapted varieties. Other efforts investigated amending upland soils to improve soil properties (Dale et al., 1989; Goulart et al., 1998), optimizing management inputs to maximize tolerance to upland soil (Chandler et al., 1984; Erb et al., 1993; Korcak, 1983), and growing blueberries in a potting medium, similar to that used in the container nursery industry (Smolarz, 1985). However, the cost of potting mixes or their components as soil amendments may be prohibitively expensive for fruit production, even on a small scale.

In regions with coal-fired electrical generation, coal combustion by-products may provide a relatively low cost substrate for plant growth. Several of these combustion by-products, such as fly ash, bottom ash, and fluidized bed combustion by-product, have desirable horticultural characteristics, are available at low cost, and are

Received for publication 29 Nov. 2001. Accepted for publication 24 Apr. 2002. The authors gratefully acknowledge the technical support of Ingrid Fordham and Philip Edmonds. We also thank Ron Korcak for helpful input through all stages of this project. We thank Rufus Chaney for reviewing the data presented here, and Mark Ehlenfeldt for helpful review of the manuscript.

${ }^{1}$ E-mail blackb@ba.ars.usda.gov.

${ }^{2}$ Retired. currently being under-used (Korcak, 1993). Bottom ash has a particle size ranging from 0.1 to $10 \mathrm{~mm}$, and may contain usable levels of micronutrients. However, these materials may also have a basic $\mathrm{pH}$ and contain phytotoxic levels of some elements, or have appreciable levels of elements considered environmental contaminants. Elemental content of these products depends on coal source, and whether or not the coal was cleaned before combustion (Korcak, 1993). Bottom ash was used in our studies as a substitute for sand. A wide range of materials are now being composted by commercial facilities. We selected two commercial composts to represent different classes of materials. One was a sewage sludge or biosolids compost, and the other was primarily a leaf compost from a yard waste recycling program.

We conducted a multiyear study to evaluate bottom ash and compost as components of soil-free media for highbush blueberry production. Comparison treatments included a typical blueberry soil, and an upland clay loam soil either alone or compost amended.

\section{Materials and Methods}

Media TREATMENTs. Bottom ash was obtained from the PEPCO Chalk Point power plant in Prince Georges County, Md. A biosolids compost was obtained from a commercial composting facility at the Baltimore, Md., waste water treatment facility. A commercial leaf compost (Leafgro) was obtained from a yard-waste recycling program in Montgomery County, Md., and acid peatmoss was obtained from a commercial source. These components were then combined in the proportions listed in Table 1, to give six experimental media treatments. Controls included Berryland sand (Typic Haplaquad, Coastal Plain soil) obtained from the Philip E. Marucci Center for Blueberry and Cranberry Research and Extension, Chatsworth, N.J., and Manor clay loam soil (Typic Dystrocrept, Piedmont soil) collected from the Henry A. Wallace Beltsville Agricultural Research Center, Md. Properties of these soils have been previously reported (Korcak, 1986). Treatments of Manor clay loam with compost amendment at $25 \%$ and $50 \%$ of soil volume were also included. The initial $\mathrm{pH}$ of Berryland sand was 4.0 and the $\mathrm{pH}$ of the remaining media treatments were lowered with the addition of powdered sulfur. Samples of the ash-compost mixes and the soilcompost mixes were titrated with nitric acid, and sulfur requirements were calculated for a target $\mathrm{pH}$ of 4.5 (Brown and Chaney, 
personal communication). Sulfur was added to the treatment mixes 2 weeks before planting, and media were again mixed just prior to planting.

At the time of composting the treatment mixes, samples of components were collected, dried and later sent to the agricultural analytical services laboratory at Pennsylvania State University for analysis (Table 2). Media components were analyzed according to protocols for determining the suitability of biosolids for agricultural application (U.S. Environmental Protection Agency, 1986, 1993). Total P, K, Ca, Mg, Na, Fe, Al, Mn, As, Cd, Cr, Cu, Pb, Hg, Mo, Ni, $\mathrm{Se}$, and $\mathrm{Zn}$ were determined according to U.S. Environmental Protection Agency (EPA) methods 3050/3051, 6010, 7060, and 7740 (U.S. EPA, 1986). Total N was determined by Kjeldahl digestion (Isaac and Johnson, 1976).

Plant culture. In Spring 1997, 1-year-old tissue culture plants of 'Bluecrop' and 'Sierra' blueberries were obtained from a com-

Table 1. Composition of media treatments expressed as percent. Components include Manor clay loam soil, bottom ash from coal-fired power plant (ash), municipal biosolid waste compost, Leafpro, leaf compost from a yard-waste recycling program (leaf), and Michigan acid peatmoss (peat). Treatment 1 was an unamended Berryland sand.

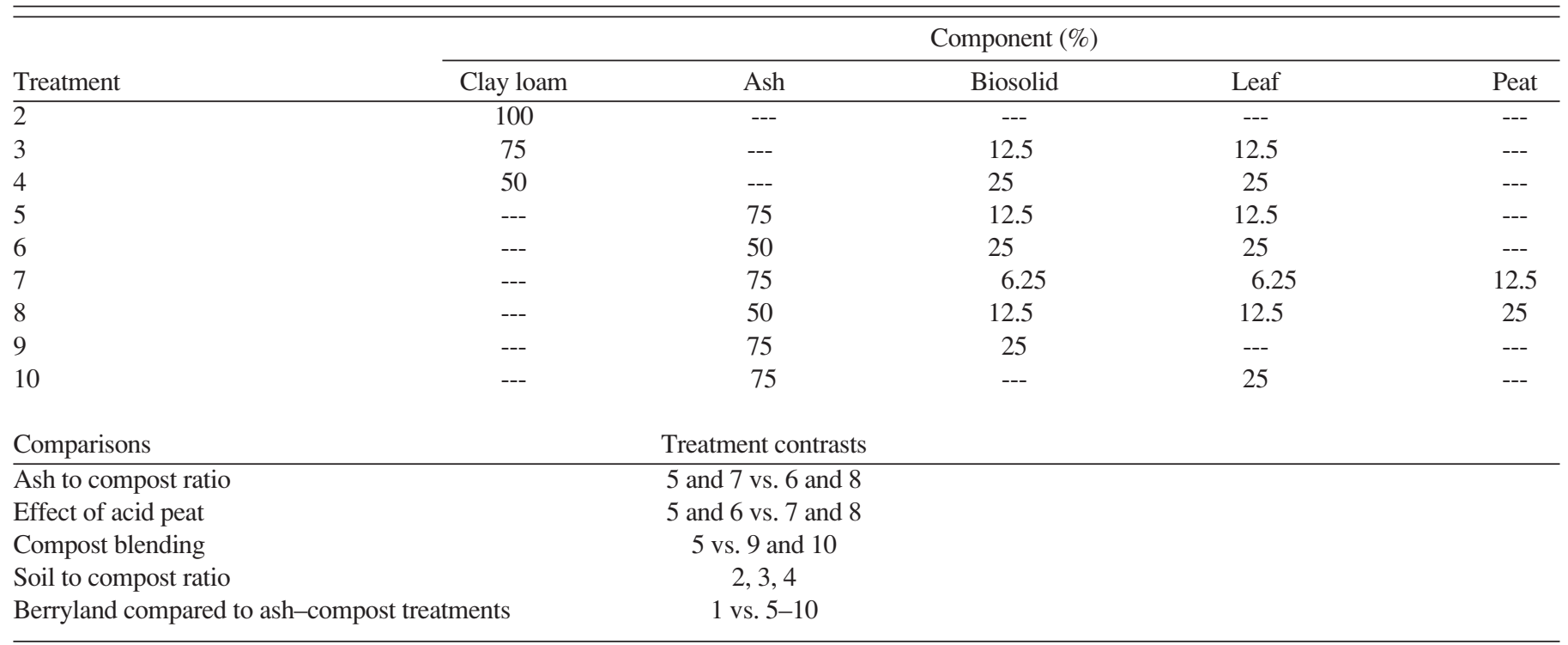

Table 2. Elemental analysis of media components. Environmental Protection Agency (EPA) alternative pollutant limits (APL) for agricultural use of biosolids are shown for comparison.

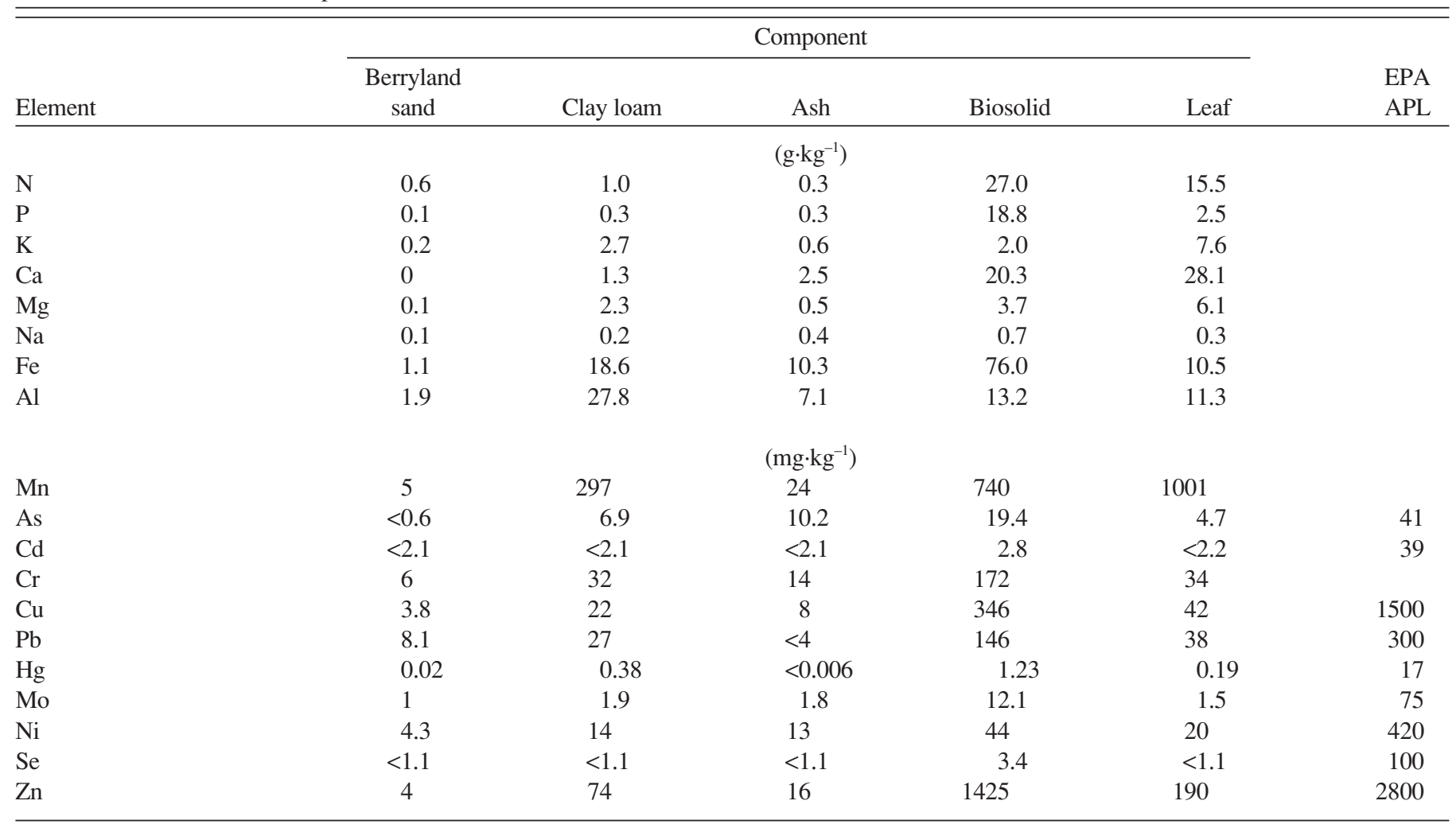


Table 3. pH of treatment media on 24 July 1997, 8 June 1999, and 10 Aug. 1999 (single observation pooled across replication), and on Dec. 1999, and Dec. 2000 (means of five replications).

\begin{tabular}{|c|c|c|c|c|c|c|c|c|c|}
\hline Media & $\begin{array}{l}\text { July } \\
1997\end{array}$ & \multicolumn{2}{|c|}{ June 1999} & \multicolumn{2}{|c|}{ Aug. 1999} & \multicolumn{2}{|c|}{ Dec. 1999} & \multicolumn{2}{|c|}{ Dec. 2000} \\
\hline 1 & 3.8 & 6.9 & 6.6 & 7.0 & 7.2 & 5.1 & 4.6 & 5.7 & 5.6 \\
\hline 3 & 6.0 & 6.5 & 6.1 & 5.5 & 5.5 & 5.2 & 5.5 & 5.3 & 5.5 \\
\hline 4 & 5.7 & 6.5 & 6.5 & 6.0 & 5.7 & 5.5 & 5.4 & 5.6 & 5.6 \\
\hline 5 & 5.5 & 6.6 & 6.7 & 7.2 & 7.4 & 6.0 & 5.8 & 6.4 & 6.0 \\
\hline 8 & 6.2 & 6.6 & 6.9 & 6.8 & 6.7 & 5.8 & 5.7 & 5.9 & 6.3 \\
\hline 9 & 5.4 & 6.6 & 6.7 & 7.4 & 7.3 & 5.9 & 5.6 & 6.3 & 6.2 \\
\hline 10 & 5.2 & 6.7 & 6.6 & 7.6 & 7.5 & 5.9 & 5.9 & 6.5 & 6.3 \\
\hline \multicolumn{6}{|c|}{ Analysis of variance } & \multicolumn{2}{|c|}{ Dec. 1999} & \multicolumn{2}{|c|}{ Dec. 2000} \\
\hline \multicolumn{4}{|c|}{ Ash to compost ratio $(5,7$ vs. 6,8$)$} & & & & $*$ & & NS \\
\hline \multicolumn{10}{|c|}{ Clay } \\
\hline Line & & & & & & $* *$ & NS & \multicolumn{2}{|c|}{$* * *$} \\
\hline Qua & & & & & & $*$ & NS & \multicolumn{2}{|c|}{ NS } \\
\hline \multicolumn{4}{|c|}{ Berryland vs. ash to compost ( 1 vs. $5-10)$} & & & $* * *$ & $* * *$ & \multicolumn{2}{|c|}{$* * *$} \\
\hline
\end{tabular}

$\overline{\mathrm{NS},{ }^{*}, * *, * * *}$ Nonsignificant or significant at $P \leq 0.05,0.01$, or 0.001 , respectively.

Table 4. Macronutrient element composition of leaves collected 28-30 July 1998. Samples were analyzed at a commercial laboratory.

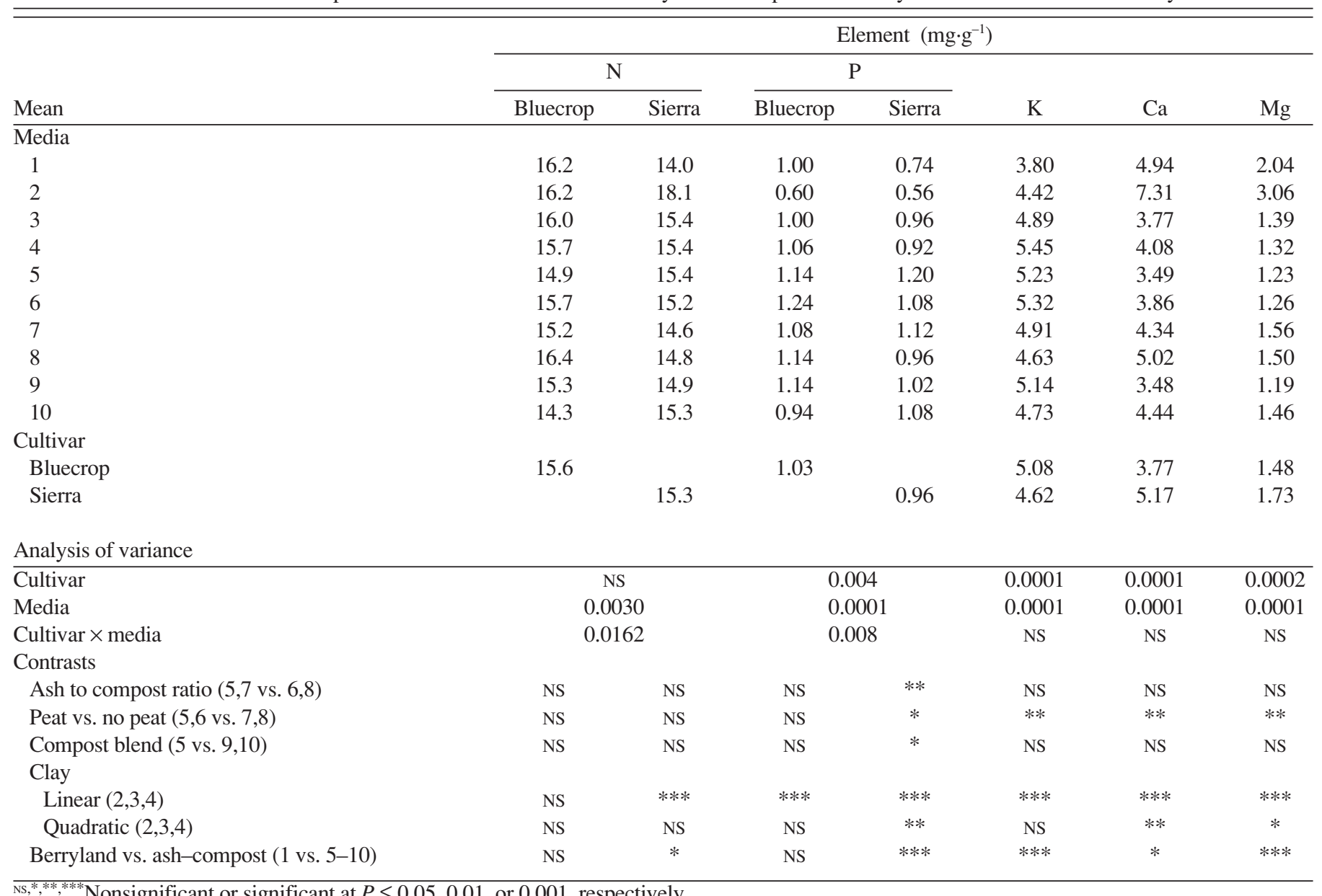


mercial nursery and planted singly in $15-\mathrm{dm}^{3}$ plastic pots containing $\mathrm{pH}$-adjusted treatment media. The planting was arranged as a randomized complete block design with five blocks, and two plants per treatment, cultivar and block. Irrigation water was provided uniformly by a trickle irrigation system. Due to the differences in water holding capacity, the clay loam treatment may have been periodically over-watered. Plants were fertilized in July 1997 with 21-7-7 fertilizer at a rate of $0.30 \mathrm{~g} \mathrm{~N} /$ plant. Ammonium sulfate fertilizer was applied 19 May 1998 and 9 July 1998 at a rate of 0.77 g N per plant, and on 20 May 1999, 9 July 1999, and 17 May 2000 at $2.57 \mathrm{~g} \mathrm{~N} /$ plant. After the first growing season, irrigation water was drawn from a different source due to the high $\mathrm{pH}(>8.0)$ of the initial water source. Media samples were collected periodically during the experiment for $\mathrm{pH}$ measurements (Table 3).

Elemental ANALYSIS. On 28-30 July 1998, 20 midshoot leaves were collected from each plant for elemental analysis. Leaves were washed in water containing $0.1 \%$ surfactant, rinsed in tap water and then distilled water before drying at $70^{\circ} \mathrm{C}$ for $48 \mathrm{~h}$. Dried leaves were ground to pass through a 30-mesh sieve and sent to the analytical services laboratory at Pennsylvania State University. Tissue concentrations of $\mathrm{P}, \mathrm{K}, \mathrm{Ca}, \mathrm{Mg}, \mathrm{Mn}, \mathrm{Fe}, \mathrm{Cu}, \mathrm{B}, \mathrm{Al}, \mathrm{Zn}, \mathrm{Na}, \mathrm{Cd}, \mathrm{Ni}, \mathrm{Pb}$, $\mathrm{Mo}$, and As were determined by inductively coupled plasma atomic emission spectrometry (Dahlquist and Knoll, 1978), and N content was determined by combustion (Campbell, 1991). During the 1999 harvest, samples of ripe fruit were collected, frozen in liquid nitrogen, lyophilized, and ground to pass a 40-mesh sieve, and analyzed for elemental content as described for leaves.
Fruit HarVest. Although there was some fruit set in 1998, the first significant harvest occurred in 1999. Ripe fruit was harvested at weekly intervals from 23 June 1999 to 19 July 1999, and at twiceweekly intervals from 9 June 2000 to 4 Aug. 2000. Total fruit weight at each harvest was determined for each plant, and subsamples of 10 randomly selected fruit were weighed to estimate mean fruit size. Yield data were analyzed as a cultivar $\times$ media factorial, with data from the two seasons treated as repeated measures.

DeSTRUCTIVE GROWTH ANALYSIS. Following the 1999 growing season, one of the two plants in each block and treatment was removed from the planting for growth analysis. Height of the two tallest stems was measured and averaged, and two perpendicular measurements of canopy spread were taken. Canopy volume was calculated from height and spread assuming a cylindrical shape (Erb et al., 1993). Each root ball was removed from the pot and the upper $10 \mathrm{~cm}$ of the root ball was separated from the remaining profile, before washing media from the roots. Stems and the upper and lower washed root masses were oven dried at $65^{\circ} \mathrm{C}$ and weighed.

Statistical analysis. Statistical analysis was carried out using the GLM procedure of the SAS program. The experiment was analyzed as a randomized complete block design with 2 cultivar $\times$ 10 media factorial treatment structure. Where factorial analysis showed cultivar $\times$ treatment interactions significant at $P<0.10$, data were analyzed separately for each cultivar.

Contrast statements were used for specific treatment comparisons (Table 1). For example, results from treatments 5 through 8 were used to compare ash to compost ratio and the effects of acid

Table 5. Micronutrient element composition of leaves collected 28-30 July 1998. Samples were analyzed at a commercial laboratory.

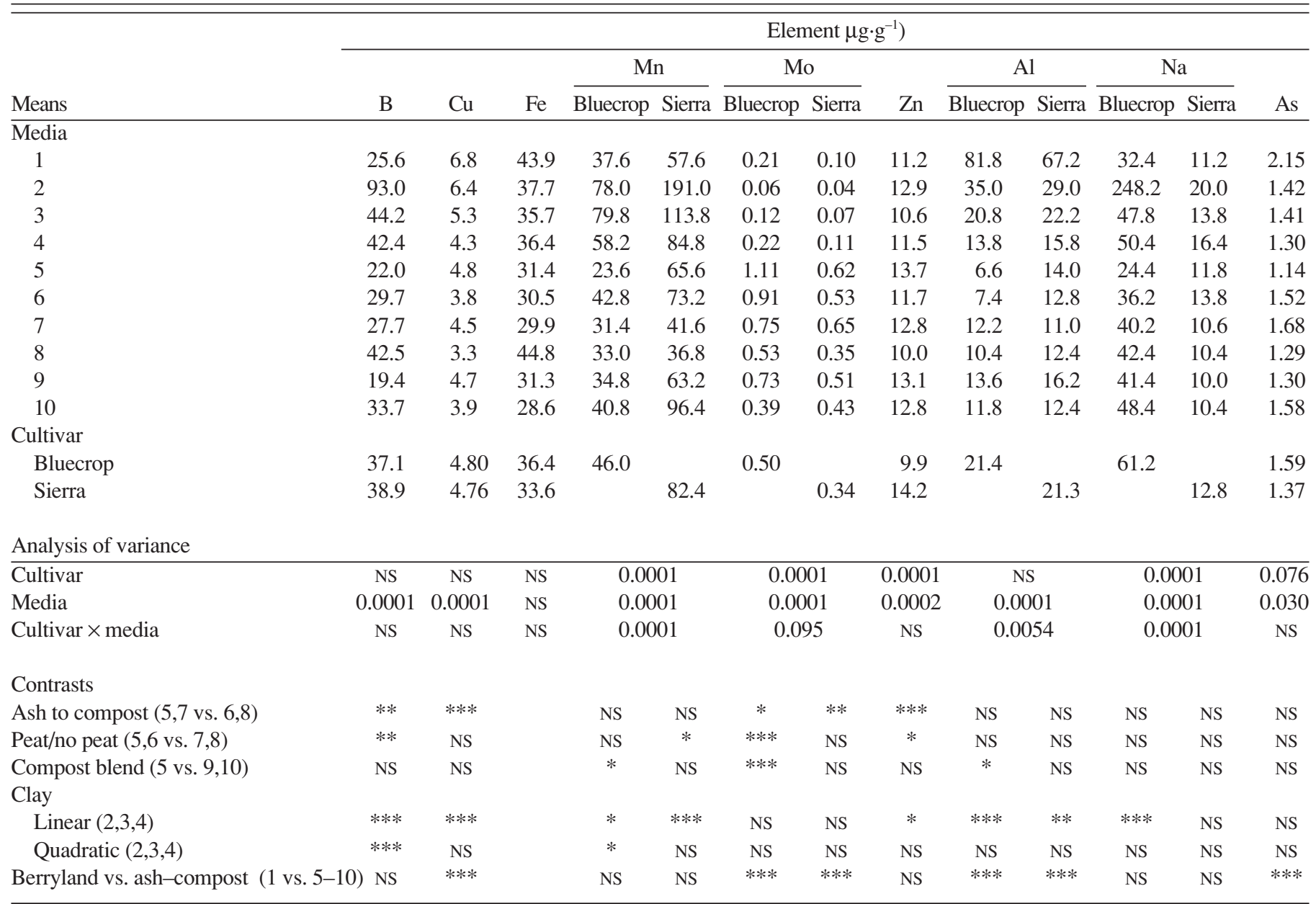

$\overline{\mathrm{NS}^{*}, * *, * * * *}$ Nonsignificant or significant at $P \leq 0.05,0.01$, or 0.001 , respectively. 
peatmoss addition. Treatment 5 was compared to 9 and 10 to determine the effects of using a blend of the composts compared to the individual composts used separately. Contrast statements were used to test for linear and quadratic trends of amending clay loam soil with compost.

\section{Results and Discussion}

Media components and soils were analyzed for elemental content, and levels of $\mathrm{As}, \mathrm{Cd}, \mathrm{Cr}, \mathrm{Cu}, \mathrm{Pb}, \mathrm{Hg}, \mathrm{Mo}, \mathrm{Ni}, \mathrm{Se}$, and $\mathrm{Zn}$ were compared to Alternative Pollutant Limits (APL) set by the U.S. EPA for land application of biosolids (U.S. EPA, 1993). None of the media components or soils exceeded the APL for any of these elements. Levels of $\mathrm{Cd}, \mathrm{Hg}$, and Se were $<5 \%$ of ceiling limits in all components (Table 2). Levels of $\mathrm{Cu}, \mathrm{Pb}, \mathrm{Mo}, \mathrm{Ni}$, and $\mathrm{Zn}$ were $<10 \%$ of APL for all components except biosolid compost, where levels were $23.0 \%, 48.5 \%, 16.1 \%, 10.4 \%$, and $50.9 \%$ of ceiling limits, respectively. Levels of As were $16.8 \%$ and $24.9 \%$ of APL for Manor clay loam and coal ash, respectively. Leafpro compost had As levels that were $11.5 \%$ of ceiling limits, compared to $47.3 \%$ for biosolid compost. Although early studies indicated that heavy metal content of biosolids might be problematic, this is no longer the case with modern high-quality biosolids composts (Sommers, 1977; U.S. EPA, 1990). The results from the analysis of compost from our source were consistent with that of a typical high-quality compost.

The chemical composition of coal ash varies with the source and type of coal, and the type of combustion process used (Korcak, 1993). Although coal ash may be a source of a number of the essential macro- and micronutrients ( $\mathrm{Ca}, \mathrm{Fe}, \mathrm{Mg}, \mathrm{K}, \mathrm{B}, \mathrm{Cu}, \mathrm{Mn}, \mathrm{Mo}$, $\mathrm{Zn}$ ), some of these may occur at levels that are phytotoxic. Other less favorable components of coal ash may include appreciable levels of $\mathrm{Al}, \mathrm{As}, \mathrm{Cd}, \mathrm{Na}, \mathrm{Ni}, \mathrm{Cr}, \mathrm{Pb}$ and others (Korcak, 1993). None of these were found in appreciable concentrations in the bottom ash used for these studies.

LEAF ELEMENTAL CONTENT. Leaf samples collected during the second growing season (1998) were analyzed for elemental content to determine whether uptake or accumulation of nutrients or metals were adversely affected by treatment media (Tables 4 and 5). There were significant treatment differences both among media and between cultivars. It should be noted however, that there were also significant treatment differences in overall plant growth. Consequently, differences in leaf elemental content may be due in part to a dilution effect. Unless otherwise indicated, leaf macro and micro nutrient concentrations were compared to thresholds for deficient, sufficient and excessive concentrations as found in Hanson et al. (1992) and Hanson and Hancock (1996).

Although there were significant treatment differences in leaf $\mathrm{N}$ content, these differences were only found in 'Sierra', where leaf $\mathrm{N}$ was significantly lower for Berryland sand, and significantly higher for unamended Manor clay loam (Table 4). In most cases, leaf $\mathrm{N}$ content indicated slight deficiencies relative to the recommended range of 17 to $21 \mathrm{mg} \cdot \mathrm{g}^{-1}$. Concentrations of leaf $\mathrm{P}$ also differed

Table 6. Macronutrient content of fruit. Fruit samples were collected during the 1999 harvest. Fruit was frozen in liquid nitrogen, lyophilized and ground to pass a 40-mesh filter. Samples were sent to a commercial laboratory for elemental analysis as described for leaf samples.

\begin{tabular}{|c|c|c|c|c|c|c|c|}
\hline \multirow[b]{3}{*}{ Means } & \multicolumn{7}{|c|}{ Element $\left(\mathrm{mg} \cdot \mathrm{g}^{-1}\right)$} \\
\hline & \multirow[b]{2}{*}{$\mathrm{N}$} & \multicolumn{2}{|c|}{$\mathrm{P}$} & \multirow[b]{2}{*}{$\mathrm{K}$} & \multirow[b]{2}{*}{$\mathrm{Ca}$} & \multicolumn{2}{|c|}{$\mathrm{Mg}$} \\
\hline & & Bluecrop & Sierra & & & Bluecrop & Sierra \\
\hline 1 & 5.59 & 0.538 & 0.506 & 5.16 & 0.680 & 0.448 & 0.406 \\
\hline 2 & 6.55 & 1.014 & 0.394 & 5.61 & 0.916 & 0.705 & 0.364 \\
\hline 3 & 6.80 & 0.822 & 0.794 & 5.69 & 0.800 & 0.492 & 0.384 \\
\hline 6 & 5.83 & 0.870 & 0.802 & 5.00 & 0.930 & 0.584 & 0.444 \\
\hline 7 & 6.38 & 0.722 & 0.680 & 5.49 & 1.050 & 0.636 & 0.498 \\
\hline 8 & 6.25 & 0.788 & 0.708 & 4.79 & 0.910 & 0.544 & 0.446 \\
\hline 9 & 5.83 & 0.694 & 0.674 & 5.32 & 0.950 & 0.568 & 0.482 \\
\hline 10 & 6.35 & 0.508 & 0.502 & 5.34 & 0.990 & 0.590 & 0.470 \\
\hline \multicolumn{8}{|l|}{ Analysis of variance } \\
\hline Cultivar & 0.0005 & \multicolumn{2}{|c|}{0.0001} & 0.0001 & 0.0012 & \multicolumn{2}{|c|}{0.0001} \\
\hline Media & 0.0263 & \multicolumn{2}{|c|}{0.0001} & 0.0008 & 0.0001 & \multicolumn{2}{|c|}{0.0001} \\
\hline Cultivar $\times$ media & NS & \multicolumn{2}{|c|}{0.0001} & NS & NS & \multicolumn{2}{|c|}{0.0583} \\
\hline \multicolumn{8}{|l|}{ Contrasts } \\
\hline Ash to compost ratio $(5,7$ vs. 6,8$)$ & NS & $* *$ & $*$ & $* * *$ & * & NS & NS \\
\hline Peat vs. no peat $(5,6$ vs. 7,8$)$ & $*$ & NS & NS & NS & NS & NS & NS \\
\hline Compost blend (5 vs. 9,10 ) & $*$ & $* *$ & $*$ & NS & NS & NS & NS \\
\hline \multicolumn{8}{|l|}{ Clay } \\
\hline Linear $(2,3,4)$ & NS & $*$ & $* * *$ & NS & NS & $* *$ & NS \\
\hline Quadratic $(2,3,4)$ & NS & NS & $*$ & NS & NS & NS & NS \\
\hline
\end{tabular}

NS, ${ }^{*}, * * * * * *$ Nonsignificant or significant at $P \leq 0.05,0.01$, or 0.001 , respectively. 
among media treatments, where ash-compost treatments generally had higher leaf $\mathrm{P}$ levels than did the soil controls. The lowest levels were found in the unamended clay loam, while P levels for the remaining media treatments were above the $0.8 \mathrm{mg} \cdot \mathrm{g}^{-1}$ threshold for sufficiency. Leaf $\mathrm{K}, \mathrm{Ca}, \mathrm{Mg}$, and B levels showed significant differences due to clay loam content, and peatmoss amendment (Tables 4 and 5). However, levels for all treatments were well within ranges considered sufficient. Leaf $\mathrm{Cu}$ content was significantly higher in both soil controls than in the remaining treatments where levels were below the $5 \mu \mathrm{g} \cdot \mathrm{g}^{-1}$ deficiency threshold.

There were no significant cultivar or media treatment differences in leaf Fe content, and levels in all treatments indicated potential Fe deficiency. Although Fe deficiency symptoms are common in highbush blueberry (Hanson and Hancock, 1996), leaf analysis data must be interpreted carefully as published sufficiency ranges may not be diagnostic for blueberry (Korcak, 1988b). Leaf Mn levels in the ash-compost treatments were similar to that of Berryland sand, but significantly lower than that of clay loam treatments. Blueberry and other calcifuges are Mn accumulators (Korcak, 1988b, 1988c), but concentrations reported here are well below the $450 \mu \mathrm{g} \cdot \mathrm{g}^{-1}$ threshold considered excessive. Although there were statistically significant trends in leaf $\mathrm{Zn}$ concentration related to the ash and peatmoss content of the treatment media, the magnitude of differences was small and all treatments fell within the sufficiency range (Table 5). Al toxicity is commonly associated with soil pH below 5.0 (Adams, 1981), but leaf $\mathrm{Al}$ concentrations reported here are well below those previously reported for the shoots of plants grown on Berryland sand $\left(300 \mu \mathrm{g} \cdot \mathrm{g}^{-1}\right)$ and acidified Manor clay loam (1200 to $1700 \mu \mathrm{g} \cdot \mathrm{g}^{-1}$ ) (Korcak, 1986; Korcak et al., 1982).

Leaf content of $\mathrm{Cd}, \mathrm{Pb}$, and $\mathrm{Co}$ were at or below detection limits of $0.02,0.13$, and $0.02 \mu \mathrm{g} \cdot \mathrm{g}^{-1}$, respectively (data not shown). Mean $\mathrm{Cr}$, Ni and Se levels were $0.34,0.44$, and $0.86 \mu \mathrm{g} \cdot \mathrm{g}^{-1}$, respectively, and did not differ significantly among treatments. Although there were significant differences in As content, the highest levels were found in the Berryland control with $2.15 \mu \mathrm{g} \cdot \mathrm{g}^{-1}$, compared to values ranging from 1.14 to $1.68 \mu \mathrm{g} \cdot \mathrm{g}^{-1}$ for ash-compost treatments. This treatment difference in As content may be related to the binding capacity of organic matter which could have reduced plant-available As in compost treatments (R. Chaney, personal communication).

Elemental ANALYSIS OF FRUIT. Fruit samples collected in 1999 were analyzed for elemental content to determine whether blueberry plants grown on ash-compost treatments were accumulating enough of any one element in the fruit to pose a health risk. Levels of $\mathrm{Cd}, \mathrm{Co}$, and $\mathrm{Ni}$ were below detection limits. For the remaining elements, there were statistically significant treatment differences (Tables 6 and 7), but the levels of these elements, and the magnitude of treatment differences were unexceptional, and will not be discussed in detail.

Cropping. Ripe fruit were harvested in 1999 and 2000, and total fruit yield calculated for each plant. Yield data were analyzed as a cultivar $\times$ media factorial, with data from the two seasons treated as

Table 7. Micronutrient and trace element composition of blueberry fruit. Fruit sample collection and analysis are described in Table 6. Cd, Co and Ni levels were below detection limits.

\begin{tabular}{|c|c|c|c|c|c|c|c|c|c|c|c|}
\hline \multirow[b]{2}{*}{ Means } & \multicolumn{11}{|c|}{ Element $\left(\mu \mathrm{g} \cdot \mathrm{g}^{-1}\right)$} \\
\hline & $\mathrm{B}$ & $\mathrm{Cu}$ & $\mathrm{Fe}$ & Bluecrop & $\overline{\text { Sierra }}$ & Bluecrop & $\overline{\text { Sierra }}$ & $\mathrm{Zn}$ & $\mathrm{Al}$ & Bluecrop & Sierra \\
\hline 1 & 4.10 & 4.10 & 11.50 & 5.0 & 6.8 & 0.45 & 0.19 & 6.60 & 5.60 & 26.4 & 6.4 \\
\hline 2 & 4.71 & 3.76 & 7.84 & 16.1 & 24.4 & 0.84 & 0.02 & 9.73 & 1.79 & 47.5 & 20.6 \\
\hline 3 & 5.10 & 4.40 & 10.30 & 24.2 & 15.8 & 0.26 & 0.13 & 8.70 & 2.40 & 44.6 & 17.0 \\
\hline 6 & 4.50 & 2.30 & 6.00 & 10.0 & 9.0 & 0.84 & 0.43 & 9.10 & 1.60 & 31.2 & 10.8 \\
\hline 7 & 4.60 & 2.50 & 5.30 & 5.6 & 5.2 & 0.84 & 0.55 & 8.10 & 2.10 & 29.2 & 15.8 \\
\hline 8 & 4.30 & 2.10 & 5.90 & 4.8 & 4.6 & 0.95 & 0.50 & 8.80 & 1.60 & 30.8 & 18.0 \\
\hline 9 & 4.30 & 2.70 & 8.40 & 6.2 & 7.0 & 0.69 & 0.55 & 9.10 & 1.70 & 37.6 & 11.8 \\
\hline 10 & 4.70 & 1.90 & 5.70 & 7.4 & 9.2 & 0.65 & 0.35 & 7.90 & 1.80 & 26.2 & 35.2 \\
\hline \multicolumn{12}{|l|}{ Analysis of variance } \\
\hline Cultivar & 0.001 & 0.001 & 0.007 & \multicolumn{2}{|l|}{ NS } & \multicolumn{2}{|c|}{0.001} & 0.001 & NS & \multicolumn{2}{|c|}{0.001} \\
\hline Media & 0.041 & 0.001 & 0.001 & \multicolumn{2}{|c|}{0.001} & \multicolumn{2}{|c|}{0.001} & 0.023 & 0.001 & \multicolumn{2}{|c|}{ NS } \\
\hline Cultivar $\times$ media & NS & NS & NS & \multicolumn{2}{|c|}{0.089} & \multicolumn{2}{|c|}{0.001} & NS & NS & \multicolumn{2}{|c|}{0.080} \\
\hline \multicolumn{12}{|l|}{ Contrasts } \\
\hline Ash to compost ratio (5,7 vs. 6,8$)$ & NS & NS & NS & NS & NS & NS & NS & NS & NS & NS & NS \\
\hline Peat vs. no peat $(5,6$ vs. 7,8$)$ & NS & NS & NS & NS & NS & NS & $*$ & NS & NS & NS & NS \\
\hline Compost blend ( 5 vs. 9,10$)$ & NS & NS & NS & NS & NS & $* *$ & NS & NS & NS & NS & NS \\
\hline \multicolumn{12}{|l|}{ Clay } \\
\hline Linear $(2,3,4)$ & NS & NS & NS & NS & $* * *$ & $*$ & $* * *$ & NS & NS & NS & NS \\
\hline Quadratic $(2,3,4)$ & NS & $* *$ & NS & $* * *$ & NS & $*$ & NS & NS & NS & NS & NS \\
\hline
\end{tabular}

NS, ${ }^{*},{ }^{* * * * *}$ Nonsignificant or significant at $P \leq 0.05,0.01$, or 0.001 , respectively. 
repeated measures. The main effects of cultivar and media treatment were significant at $P<0.0001$. The main effect of year was significant at $P<0.001$, and media $\times$ year and cultivar $\times$ year terms were significant at $P<0.01$ and $P<0.05$, respectively. These year and media $\times$ year effects can be attributed to several factors. First, fruiting was delayed in several of the slower growing treatments such as 'Bluecrop' in clay loam soil. In these cases, yields increased dramatically from the first to the second fruiting year (Fig. 1A). Second, in media treatments that resulted in rapid plant growth, plants quickly reached the capacity of the $15-\mathrm{dm}^{3}$ pots. Consequently, yields were relatively high during the first fruiting year, but the same or lower the following season (Fig. 1B-C). Because of these year $\times$ treatment interactions, cumulative yields over the two seasons are presented as a stacked bar graph in Fig. 1, and contrasts of media treatments are presented for cumulative yields.

There were dramatic differences in fruit yield among media treatments, with the lowest yields found in the unamended clay loam
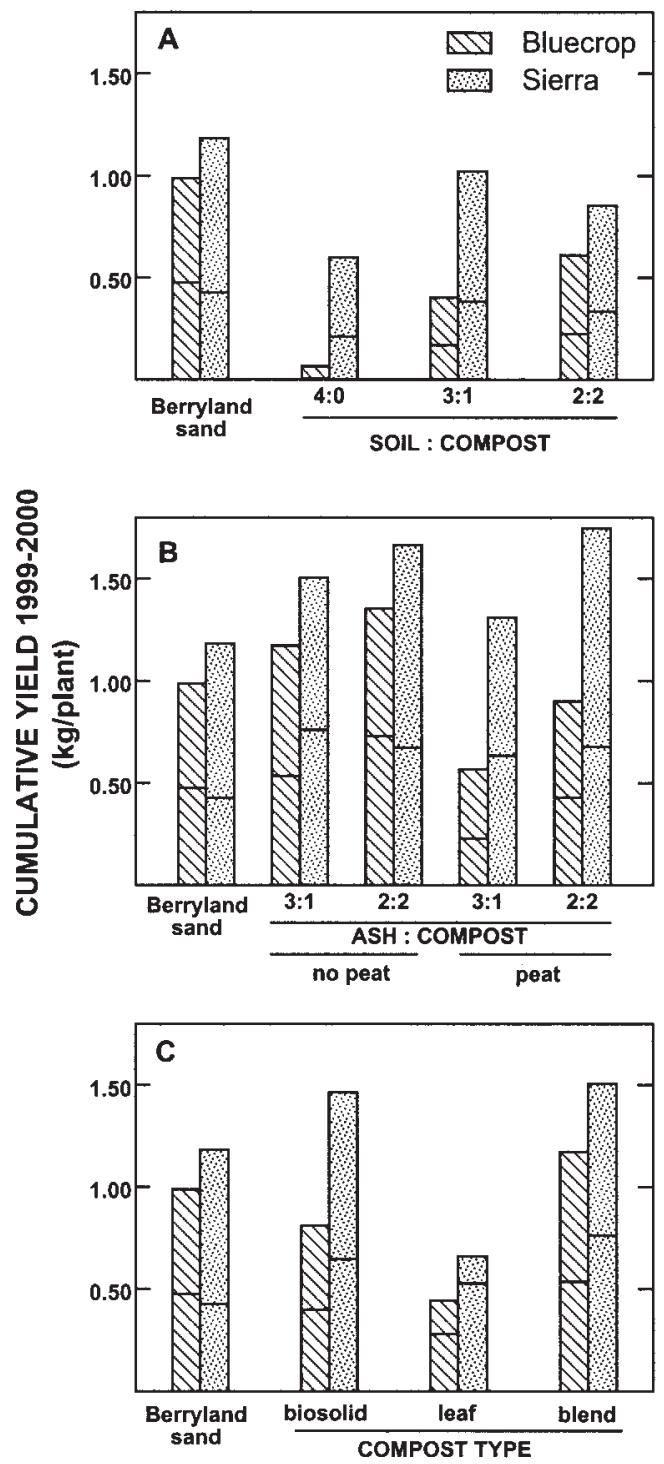

Fig. 1. Cumulative fruit yields (kg/plant) in 1999 and 2000. The lower and upper portions of each bar represent yields for the 1999 and 2000 harvests, respectively. Individual comparisons show the effects of (A) amending Manor clay loam with blended compost, (B) ash to compost ratio and presence of peatmoss, and (C) a comparison of unblended yard waste compost, biosolid compost, and a combination of these. The control treatment of Berryland sand is shown in each graph for comparison. control. Amending clay loam with compost improved yields, but even a 1:1 mix of soil to compost (treatment 4) produced less fruit than the Berryland control (Fig. 1A). The highest yields were found in the coal ash-compost treatments, with ash to compost ratio of $1: 1$ having significantly higher yields than that of the 3:1 treatment $(P$ $=0.020$, Fig. 1B). Treatments without peatmoss had significantly higher yields than with peatmoss $(P=0.014)$, and treatments containing either biosolid compost or blended compost had higher yields than did the treatment containing only leaf compost (Fig. 1C).

The largest mean fruit weight of $1.30 \mathrm{~g}$ berries was found in 'Bluecrop' grown in Berryland sand. The smallest mean fruit weight of $0.77 \mathrm{~g}$ berries was found in 'Bluecrop' grown in unamended clay loam. Fruit weight among ash-compost and soil-compost treatments for 'Bluecrop' was $1.08 \mathrm{~g}$ and did not differ significantly among treatments. Mean fruit weight for 'Sierra' was $1.17 \mathrm{~g}$ and there were no significant differences among media treatments (data not shown).

GrowTH ANALYSIS. There were significant cultivar and media treatment differences in plant growth and dry weight partitioning (Table 8). A number of these treatment differences were similar to those found for fruit yield, since fruit yield was significantly correlated with plant growth $(P<0.001)$. However, several of these treatment differences are instructive. First, there was a significant cultivar $\times$ media interaction for both total plant biomass and root penetration (Table 8). The nature of this interaction can be best illustrated by comparing Berryland sand and Manor clay loam controls for each cultivar. 'Bluecrop' appears to be more sensitive to soil type with greater treatment differences between Berryland sand and Manor clay loam for plant growth, root penetration, and fruit yield. These cultivar differences were expected since 'Bluecrop' was selected to represent an industry standard, and 'Sierra' is a newer cultivar perceived to be more tolerant of different soil types. One notable cultivar difference in growth parameters is that of root penetration, particularly among the most productive media treatments. For 'Bluecrop' on Berryland sand and the 1:1 ash-compost treatments, $18 \%$ to $22 \%$ of the total root biomass extended below the top $10 \mathrm{~cm}$ of media. Root penetration for 'Sierra' in the same media treatments ranged from $7 \%$ to $13 \%$. However, 'Sierra' had a higher root to shoot ratio indicating that a higher percentage of total plant biomass was partitioned to the roots, but the root system was not as deep.

Among media treatments, clay loam treatments showed very little root penetration, and higher root to shoot ratio. The plants were obtained from a commercial nursery and were growing in $0.5-\mathrm{dm}^{3}$ pots containing a standard greenhouse potting mix. Planted into unamended clay loam soil, the plants produced a dense fibrous root system that did not extend very far beyond this pocket of potting media. Amending the clay loam with compost did reduce root to shoot ratio by increasing shoot growth, but did not increase vertical root penetration.

Taken together, these data indicate that a combination of coal ash and compost provide an excellent substrate for growing highbush blueberry. For 'Bluecrop' and 'Sierra' plants maintained in $15-\mathrm{dm}^{3}$ pots, fruit yield and plant growth over the first three seasons met or exceeded that of plants grown on a typical blueberry soil. For the best ash-compost treatments, 'Bluecrop' produced average annual yields $>600 \mathrm{~g} / \mathrm{plant}$ in the third and fourth year. It is admittedly difficult to extrapolate results from these pot-culture experiments to field production, but the following is provided as a general point of reference. Assuming 2500 plants per hectare, a field planting of blueberries would be expected to yield $\approx 250$ and 500 g per plant in the third and fourth year of production, respectively (Pritts and 
Castaldi, 1992). At full maturity, a field planting of 'Bluecrop' will produce 3.6 to $5.4 \mathrm{~kg} / \mathrm{plant}$ annually (M. Ehlenfeldt, personal communication). The maximum potential for cropping in ashcompost mixes has yet to be determined, but plants in this study were clearly reaching the limits of the pot volume provided.

The purpose of this research was to investigate the horticultural aspects of using these materials as substrates, and not to evaluate the economic feasibility of this approach. Clearly, these materials are not practical for large-scale commercial fruit production. However, for a small-scale diversified operation interested in producing highvalue fruit for direct market, but without suitable soil for highbush blueberry production, this may represent an economically viable approach. Coal combustion by-products are often freely available, with transportation representing the major cost of using these materials. Proximity to a source of clean, high quality coal ash will determine the viability of this approach.

As with composts from different sources, it should be noted that there are a wide range of coal combustion by-products, with varied chemical and physical properties. Also, the chemical composition of any one combustion by-product, such as bottom ash, can vary with the source and type of coal, and the type of combustion process used (Korcak, 1993). When considering the use of a coal combustion by-product or a compost as a substrate, a component of a blended media, or as a soil amendment, good horticultural practices would dictate detailed elemental analysis with particular attention to those elements that may induce phytotoxicity, or exceed regulatory standards based on risk assessment research (U.S. EPA, 1993).

These experiments were limited in scale, using relatively small volumes of treatment media, comparing only two blueberry cultivars and two compost sources. In addition, horticultural practices were directed at optimizing the growth and plant health of the entire experiment, and not specifically tailored to each media treatment or cultivar, whereas optimizing water and nutrient management for each media would further improve growth and yield (Chandler et al., 1984; Erb et al., 1993; Korcak, 1983). Additional research is needed to compare different compost sources, to optimize ash and compost content, and to determine minimum root-zone volume required for long term growth and productivity. Additional cultivars will also need to be compared for adaptability to this system, and guidelines will need to be developed for horticultural practices such as managing crop load, irrigation, and plant nutrition.

\section{Literature Cited}

Adams, F. 1981. Nutritional imbalances and constraints to plant growth on acid soils. J. Plant Nutr. 4:81-87.

Campbell, C.R. 1991. Determination of total nitrogen in plant tissue by combustion, p. 21-23. In: C.O. Plank (ed.). Plant analysis reference procedures for the southern region of the United States. Univ. Ga. Agr.

Table 8. Nondestructive and destructive measurements of plant growth. Canopy volume was calculated from two measurements of plant height and two perpendicular measurements of canopy spread (Erb et al., 1993) assuming a cylindrical shape. Total biomass and root to shoot (R:S) ratios were determined from stem and root dry weights. Root penetration is the percent of total root biomass extending more than $10 \mathrm{~cm}$ below the soil surface.

\begin{tabular}{|c|c|c|c|c|c|c|}
\hline Means & $\begin{array}{c}\text { Canopy } \\
\text { vol } \\
\mathrm{dm}^{3}\end{array}$ & \multicolumn{2}{|c|}{$\begin{array}{c}\text { Total } \\
\text { biomass } \\
(\mathrm{g})\end{array}$} & $\begin{array}{l}\mathrm{R}: \mathrm{S} \\
\text { ratio }\end{array}$ & \multicolumn{2}{|c|}{$\begin{array}{c}\text { Root } \\
\text { penetration }(\%)\end{array}$} \\
\hline \multicolumn{7}{|l|}{ Media } \\
\hline 1 & 163 & 402 & 289 & 1.179 & 21.30 & 9.72 \\
\hline 2 & 68 & 70 & 228 & 1.912 & 0.62 & 5.77 \\
\hline 5 & 163 & 183 & 270 & 0.945 & 7.41 & 6.90 \\
\hline 6 & 267 & 305 & 324 & 0.839 & 22.16 & 7.26 \\
\hline 7 & 125 & 138 & 256 & 0.937 & 9.33 & 5.20 \\
\hline 8 & 180 & 208 & 351 & 0.907 & 17.97 & 13.2 \\
\hline 9 & 156 & 120 & 273 & 1.029 & 5.56 & 14.1 \\
\hline \multicolumn{7}{|l|}{ Cultivar } \\
\hline \multicolumn{7}{|l|}{ Analysis of variance } \\
\hline Cultivar & 0.0001 & \multicolumn{2}{|c|}{0.0001} & 0.0036 & \multicolumn{2}{|c|}{0.043} \\
\hline Media & 0.0001 & \multicolumn{2}{|c|}{0.0001} & 0.0001 & \multicolumn{2}{|c|}{0.0001} \\
\hline Cultivar $\times$ media & NS & \multicolumn{2}{|c|}{0.0126} & NS & \multicolumn{2}{|c|}{0.0061} \\
\hline \multicolumn{7}{|l|}{ Contrasts } \\
\hline Ash to compost ratio $(5,7$ vs. 6,8$)$ & $* * *$ & $* *$ & NS & NS & $* *$ & NS \\
\hline Peat vs. no peat $(5,6$ vs. 7,8$)$ & $* *$ & NS & NS & NS & NS & NS \\
\hline Compost blend (5 vs. 9,10 ) & NS & NS & NS & NS & NS & NS \\
\hline \multicolumn{7}{|l|}{ Clay } \\
\hline Linear $(2,3,4)$ & NS & NS & NS & $* * *$ & NS & NS \\
\hline
\end{tabular}

$\overline{\mathrm{Ns}, *, * * * * * *}$ Nonsignificant or significant at $P \leq 0.05,0.01$, or 0.001 , respectively. 
Expt. Sta. S. Coop. Ser. Bul. 368.

Chandler, C.K., R.F. Korcak, and A.D. Draper. 1984. Analysis of leaf and soil samples from a planting of blueberry seedlings growing on unmulched, upland soil. Ohio Agr. Expt. Sta. Dev. Ctr. Res. Circ. (Aug.):69-71.

Dahlquist, R.L. and J.W. Knoll. 1978. Inductively coupled plasma atomic emission spectrometer: Analysis of biological materials and major, trace and ultra-trace elements. Appl. Spectroscopy 32:1-29.

Dale, A., R.A. Cline, and C.L. Ricketson. 1989. Soil management and irrigation studies with highbush blueberries. Acta Hort. 241:120-125.

Eck, P. and N.F. Childers. 1966. The blueberry industry, p. 3-13. In: P.Eck and N.F. Childers (eds.). Blueberry culture. Rutgers Univ. Press, New Brunswick, N.J.

Eck, P., R.E. Gough, I.V. Hall, and J.M. Spiers. 1990. Blueberry management, p. 273-301. In: G.J. Galletta and D.G. Himelrick (eds.). Small fruit crop management. Prentice Hall, Englewood Cliffs, N.J.

Erb, W.A., A.D. Draper, and H.J. Swartz. 1993. Relation between moisture stress and mineral soil tolerance in blueberries. J. Amer. Soc. Hort. Sci. 118:130-134.

Finn, C.E., J.J. Luby, C.J. Rosen and P.D. Ascher. 1993a. Blueberry germplasm screening at several soil $\mathrm{pH}$ regimes. I. Plant survival and growth. J. Amer. Soc. Hort. Sci. 118:377-382.

Finn, C.E., C.J. Rosen, J.J. Luby, and P.D. Ascher. 1993b. Blueberry germplasm screening at several soil $\mathrm{pH}$ regimes. II. Plant nutrient composition. J. Amer. Soc. Hort. Sci. 118:383-387.

Goulart, B.L., K. Demchak, and W.Q. Wang. 1998. Highbush blueberry root systems: Cultural management effects on root system development and mycorrhizal infection intensity. Proc. $8^{\text {th }}$ N. Amer. Blueberry Workers Conf. p. 140-148.

Hanson, E. and J. Hancock. 1996. Managing the nutrition of highbush blueberries. Mich. State Univ. Ext. Bul. E-2011.

Hanson, E., J. Hart, and B. Strik. 1992. Nutrient management, p. 99-109 (chapter 11). In: M.P. Pritts and J. F. Hancock (eds.). Highbush blueberry production guide. vol. 55. N.E. Reg. Agr. Eng. Serv., Ithaca, N.Y.

Holley, N.R. 2000. National directory of farm markets 2000. USDAARS, Wash., D.C.

Isaac, R.A. and W.C. Johnson. 1976. Determination of total nitrogen in plant tissue using a block digestor. J. Assn. Offic. Anal. Chem. 59:98100.

Korcak, R.F. 1983. Blueberry production on upland mineral soil. Md. Fruit
Grower 1983(suppl.):102-107.

Korcak, R.F. 1986. Adaptability of blueberry species to various soil types: II. Leaf and soil analysis. J. Amer. Soc. Hort. Sci. 111:822-828.

Korcak, R.F. 1988a. Blueberry species and cultivar response to soil types. J. Small Fruit Viticult. 1:11-24.

Korcak, R.F. 1988b. Nutrition of blueberry and other calcifuges. Hort. Rev. 10:183-227

Korcak, R.F. 1988c. Response of blueberry species to excessive manganese. J. Amer. Soc. Hort. Sci. 113:189-193.

Korcak, R.F. 1989. Adaptability of blueberry species to various soil types: III. final growth and tissue analysis. J. Plant Nutr. 12:1273-1292.

Korcak, R.F. 1993. Utilization of coal combustion by-products in agriculture and horticulture. Agr. Utilization of Urban and Ind. By-Products, ASA Spec. Publ. 58:107-130.

Korcak, R.F., G.J. Galletta, and A. Draper. 1982. Response of blueberry seedlings to a range of soil types. J. Amer. Soc. Hort. Sci. 107:1153-1160.

Pritts, M.P. 1992. Site selection and preparation, p. 17-18. In: M.P. Pritts and J.F. Hancock (eds.). Highbush blueberry production guide. N.E. Reg. Agr. Eng. Serv., Ithaca, N.Y.

Pritts, M.P. and M. Castaldi. 1992. Blueberry crop budgeting, p. 156-168 (chapter 16). In: M.P. Pritts and J.F. Hancock (eds.). Highbush blueberry production guide. vol. 55. N.E. Reg. Agr. Eng. Serv., Ithaca, N.Y.

Scheerens, J.C., W.A. Erb, B.L. Goulart, and J.F. Hancock. 1999. Blueberry hybrids with complex genetic backgrounds evaluated on mineral soils: Flowering, fruit development, yield and yield components as influenced by parental species. Fruit Var. J. 53:91-104.

Smolarz, K. 1985. Growth of potted highbush blueberry plants as affected by medium and nitrogen nutrition. Acta Hort. 165:237-240.

Sommers, L.E. 1977. Chemical composition of sewage sludges and analysis of their potential use as fertilizers. J. Environ. Quality 6:225232.

U.S. Environmental Protection Agency. 1986. Test methods for evaluating solid waste. EPA/SW-846. U.S. EPA Natl. Tech. Infor. Serv., Springfield, Va.

U.S. Environmental Protection Agency. 1990. National sewage sludge survey. Availability of information and data, and expected impacts on proposed regulations: Proposed rule. Fed. Reg. 55:47248-47283.

U.S. Environmental Protection Agency. 1993.40 CFR Part 257. Standards for the use or disposal of sewage sludge: Final rules. Fed. Reg. 58:92489415. 